\title{
Emphysema following air-powder abrasive treatment for peri-implantitis
}

\author{
Sung-Tak Lee, Malavika Geetha Subu and Tae-Geon Kwon *i]
}

\begin{abstract}
Background: Subcutaneous emphysema refers to swelling caused by the presence of air or gas in the interstices of loose connective tissue. In the head and neck area, it may follow the fascial planes and is characterized by sudden swelling, crepitus on palpation, infrequent pain, and air emboli on radiography. It usually occurs as a complication in dental treatment. Some reports have described subcutaneous emphysema caused by dental procedures; however, severe emphysema related to peri-implantitis after treatment has not been documented. Accordingly, the current report describes a rare case of subcutaneous cervical emphysema resulting from the use of an air-powder abrasive device to treat peri-implantitis.
\end{abstract}

Case presentation: Based on a review of the existing literature and the present case, nine cases of subcutaneous emphysema due to air-powder abrasive device have been reported. In most cases, the emphysema resolved over time after treatment with prophylactic antibiotics; among these, two were related to peri-implantitis management.

Conclusion: Considering the frequent use of air-powder abrasive devices to treat peri-implantitis, the potential risk of iatrogenic emphysema related to this procedure needs to be addressed more extensively.

Keywords: Subcutaneous, Pneumomediastinum, Emphysema, Peri-implantitis, Air abrasive

\section{Background}

Subcutaneous emphysema is a potentially serious clinical complication of dental treatments involving forceful injection of air into connective tissue below the dermal layer [1]. Typical incidences are encountered during surgical extraction of teeth, restorative treatment, endodontic treatment, and the use of air-driven hand pieces [2]. The etiology of subcutaneous emphysema is related to traumatic, iatrogenic, incidental, or pathological events, all of which result from the introduction of gas between the tissue layers [3]. It has been commonly reported that air-driven dental instruments can also cause various degrees of subcutaneous or cervicofacial emphysema.

Peri-implantitis is an inflammatory process that occurs around an implant and is characterized by inflammation and loss of supporting marginal bone. Air-powder abrasive treatment is one efficient mechanical debridement method for the treatment of peri-implantitis. The abrasive powder is introduced into a stream of air to clean

\footnotetext{
* Correspondence: kwondk@knu.ac.kr

Department of Oral and Maxillofacial Surgery, School of Dentistry,

Kyungpook National University, 2177 Dalgubeol-daero, Jung-gu, Daegu 41940 , Republic of Korea
}

and polish the micro-rough implant surface by removing contaminated surfaces or smoothening the texture of the implant [4]. There is consensus in using air-polishing devices to manage peri-implantitis $[4,5]$; however, the risk for development of subcutaneous emphysema has been suggested [5].

The authors encountered a very rare but severe case of cervico-facial and retropharyngeal emphysema that extended to the mediastinum as a result of using airabrasive powder to treat peri-implantitis. The present report describes a case of subcutaneous cervical emphysema resulting from the use of an air-powder abrasive device to treat peri-implantitis. The ensuing discussion reviews the existing literature pertaining to the topic and emphasizes the possible risks of air-abrasive applications in the treatment of peri-implantitis.

\section{Case presentation}

A 51-year-old female with no remarkable medical history was referred by a private dental clinic for painful swelling, warmness, and difficulty with breathing. One hour before the referral, the patient underwent treatment for peri-implantitis on the buccal side of an 
implant at the right maxillary lateral incisor at a local dental clinic. To treat the peri-implantitis non-surgically, the subgingival peri-implant pocket was slightly retracted and an air-powder abrasive device was used on the exposed implant surface to clean any possible contamination. During the treatment, however, the patient began to feel facial swelling accompanied by pain, which also spread to the neck and did not disappear. The patient was immediately transferred to the authors' institution. There were no remarkable findings near the buccal gingiva around the implant (Fig. 1). However, the patient exhibited crepitus on palpation of the right face, and both eyes were swollen and shut. Visual acuity and ocular movement were intact. The patient felt discomfort during breathing but exhibited relatively stable vital signs: body temperature $36.2{ }^{\circ} \mathrm{C}$, oxygen $\left(\mathrm{O}_{2}\right)$ saturation $95-96 \%$ in room air; blood pressure 150/90 $\mathrm{mmHg}$; and heart rate, 88 beats/min. Chest radiography revealed pneumomediastinum, and enhanced computed tomography (CT) revealed bilateral interstitial air emphysema in the temporal, infratemporal, buccal and canine, submandibular, submental, retromandibular, retropharyngeal, visceral, and carotid spaces (Figs. 2 and 3). Severe subcutaneous emphysema in both sides of the neck extended to the mediastinum. However, abnormal fluid collection and mass lesions, or distinctive lymph node enlargement, were not observed at the lung and mediastinal region (Fig. 4). The patient also underwent consultation with the department of thoracic surgery and was subsequently admitted to the hospital to monitor lung condition and to prevent infection. The patient was advised not to increase intraoral air pressure. Prophylactic antibiotic medication (cephalosporin and piperacillin/tazobactam [intravenous]) was administered for 7 days with $100 \% \mathrm{O}_{2}$ supply, in addition to analgesic medication for pain control. Approximately 3 days after admission, $\mathrm{O}_{2}$ saturation

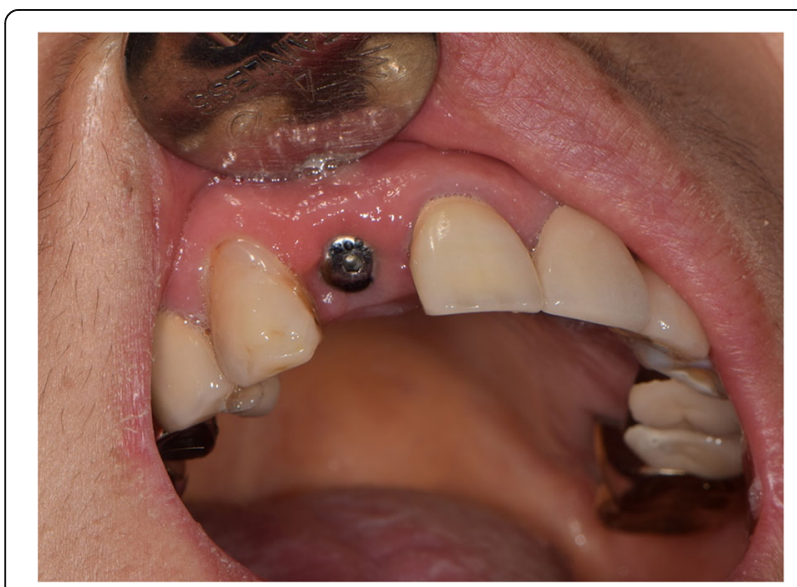

Fig. 1 Buccal aspect of the implant (\#12) treated with air-powder abrasive to manage peri-implantitis was between 98 and $100 \%$ without $\mathrm{O}_{2}$ supply. Ten days after admission, all facial and neck swelling virtually disappeared without any complications. Regular laboratory tests were conducted, and swings of infection were not observed; CT findings returned to normal. The patient was discharged 13 days after initial development of emphysema.

\section{Discussion}

It has been suggested that the cause of the subcutaneous emphysema could be classified into four categories: coughing during surgery, air forced directly into the tissue, prolonged surgical procedure(s), and no specific cause [6]. If air is further pushed, it leads to inflation of facial spaces. In worst-case scenarios, the air passes through the masticator spaces into the parapharyngeal and retropharyngeal spaces and penetrates the mediastinum [7]. It has been reported that communication between the maxillofacial fascial space and mediastinum can carry a risk for bacterial spread, potentially leading to life-threatening infections of the retropharyngeal pace and the mediastinum [8].

In mild forms of emphysema, a small amount of air is forced into the tissue causing mild swelling and crepitus. If a larger amount of air is driven into the tissue, it may lead to significant pain, increased swelling, and more crepitus [9]. It has also been reported that inadvertent introduction of air into soft tissues during procedures using high-speed, air-driven hand pieces in endodontic treatments can lead to subcutaneous and mediastinal emphysema [10].

Subcutaneous emphysema is an uncommon clinical complication of dental treatment caused by the forceful injection of air into the loose surrounding connective tissue. According to a review of 75 reported cases from 1960 to 1993 [11], emphysematous complications were caused most frequently by the use of high-speed hand pieces $(n=42)$ and air syringes $(n=27)$. Only one case of implant cleaning-related emphysema was included in that case series. Centripetal air dissection with retropharyngeal and mediastinal emphysema has occurred in many patients, especially following extractions [11]. A subsequent case review (1994-2008) involving 47 cases of subcutaneous emphysema and pneumomediastinum following dental treatment reported that air-syringe comprised 15\% (7 cases) of the total; however, the main cause was the use of a highspeed air turbine hand piece in 31 patients (66\%) [12]. Another case review reported that 16 of 32 cases (50\%) of iatrogenic subcutaneous emphysema were related to the use of air-driven hand pieces [8]. The development of pneumomediastinum after the use of air-polishing devices using abrasive powder for peri-implantitis is very rare. To our knowledge, the present report is the 


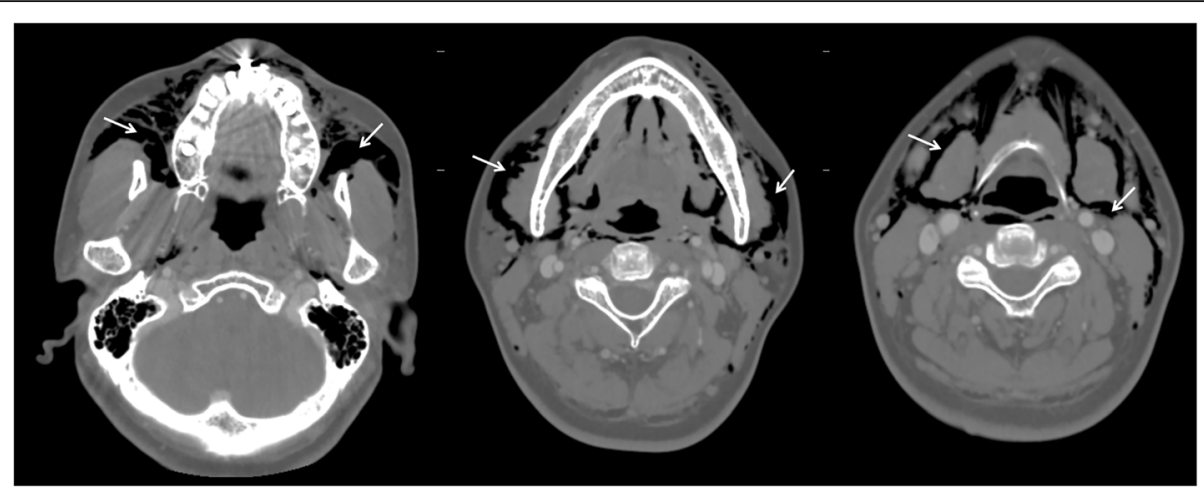

Fig. 2 Paranasal sinus computed tomography (PNS CT [axial view]) revealing multiple air bubbles of emphysema in the buccal, infratemporal, buccal and canine spaces (arrows)

first to describe extensive subcutaneous emphysema accompanying pneumomediastinum after peri-implantitis treatment using an air-abrasive device.

Previous reports, including ours, addressing subcutaneous emphysema related to air-powder abrasive devices are summarized in Table 1. There have been nine case reports, among which only two cases were related to peri-implantitis treatment-related subcutaneous emphysema. Among the nine reported cases, prophylactic antibiotics were not prescribed in three [13-15]. In one case involving a 16-year-old girl, the patient's recovery was uneventful without antibiotics, even in the presence of pneumomediastinum [14]. This difference in treatment modality may be based on severity and the patients' general condition. In most cases, the emphysema was resorbed within 7 days.

In the current case, it is uncertain why the emphysema spread widely and deeply into the bilateral neck and mediastinum. It has been suggested that the combination of air-polishing devices and abrasive powder may increase the velocity of abrasive particles [15]. At the same, a long epithelial lining at the peri-implant pocket with minimal bone-gingival attachment can be a factor in the development of emphysema after the use of airabrasive powder in peri-implantitis treatment [16]. Inadvertent angulation of the nozzle tip into a gingival pocket can also lead to this condition [17]. Therefore, careful attention should be devoted to angulation and distance between the nozzle of the air-abrasive device and the implant surface, and continuous application of the devices should be discouraged.

In treating cervico-facial and retropharyngeal emphysema extending to the mediastinum, correct diagnosis is crucial. Sudden onset of neck swelling and crepitus, tenderness, erythema, edema, or respiratory disturbance establishes the diagnosis. In this patient, mild

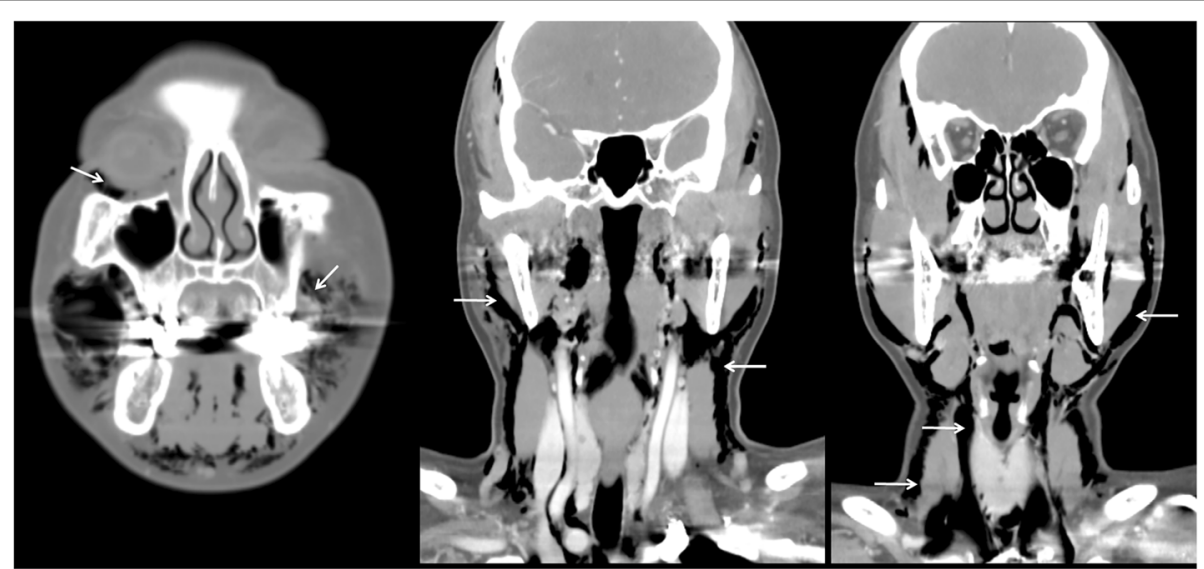

Fig. 3 Paranasal sinus computed tomography (PNS CT [coronal view]) of emphysema in the retromandibular, visceral, and retropharyngeal spaces (arrows) 


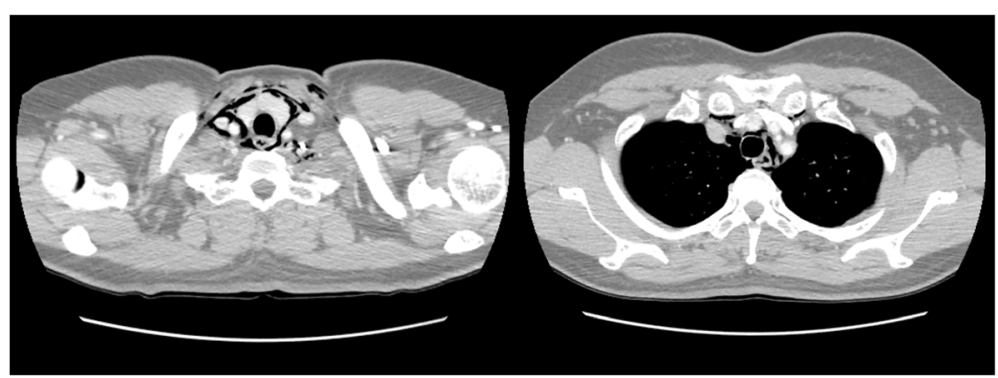

Fig. 4 Chest computed tomography revealing emphysema extending to the mediastinum

pneumothorax and pneumomediastinum were observed on posteroanterior chest X-ray and CT images. Emphysematous complications in dentistry usually have a benign course. However, extensive emphysema, similar to the case described here, requires prophylactic antibiotics, close observation of the airway, and monitoring of the progression of gas. Incision and drainage, and aggressive supportive treatment, such as chest tube placement, are sometimes necessary [18].

\section{Conclusions}

Surgical treatment is not usually needed for subcutaneous emphysema of the cervico-facial area. However, the potential risk of iatrogenic emphysema caused by the use of air-powder abrasive devices should be recognized. Considering the frequent use of air-powder abrasive devices to treat peri-implantitis, the potential risk for iatrogenic emphysema related to this procedure needs more attention.

Table 1 Subcutaneous emphysema caused by air-powder instruments (1987 to date)

\begin{tabular}{|c|c|c|c|c|c|c|}
\hline Reference & $\begin{array}{l}\text { Age, } \\
\text { years/sex }\end{array}$ & Procedure & Suspected cause & Distribution & Treatment and antibiotics & $C x$ \\
\hline $\begin{array}{l}\text { Finlayson \& Stevens } \\
\text { (1988) [17] }\end{array}$ & 49/male & Tooth stain removal & $\begin{array}{l}\text { Air polishing } \\
\left(\text { Cavi-jet }^{\circledast}\right)\end{array}$ & Subcutaneous & $\begin{array}{l}\text { Penicillin (IV) } 4 \text { times/day } \\
\text { for } 7 \text { days }\end{array}$ & - \\
\hline $\begin{array}{l}\text { Bergendal et al. } \\
\text { (1990) [13] }\end{array}$ & 40/female & $\begin{array}{l}\text { Calculus removal for } \\
\text { peri-implantitis }\end{array}$ & $\begin{array}{l}\text { Air-powder abrasive } \\
\left.\text { (Prophy-Jet }^{\oplus}\right)\end{array}$ & Subcutaneous & $\begin{array}{l}\text { Local application of } 0.2 \% \\
\text { Hibitane }^{\circledR}, \text { no infection, } \\
\text { no antibiotics }\end{array}$ & - \\
\hline $\begin{array}{l}\text { Liebenberg \& Crawford } \\
\text { (1997) [14] }\end{array}$ & 16/female & $\begin{array}{l}\text { Cleaning dental } \\
\text { stains }\end{array}$ & Air-powder abrasive & $\begin{array}{l}\text { Subcutaneous, } \\
\text { pneumomediastinum }\end{array}$ & $\begin{array}{l}\text { No antibiotics; resolved } \\
\text { within } 7 \text { days }\end{array}$ & - \\
\hline $\begin{array}{l}\text { Strassen et al. } \\
(2011) \text { [19] }\end{array}$ & 52/male & Tartar removal & $\begin{array}{l}\text { Air-powder abrasive } \\
\left(\mathrm{CaCO}_{2} \text { Powder Jet }\right)\end{array}$ & $\begin{array}{l}\text { Subcutaneous, } \\
\text { pneumomediastinum }\end{array}$ & $\begin{array}{l}\text { Sultamicin } 1.5 \mathrm{~g} \\
3 \text { times/day (IV); } \\
\text { resolved within } 4 \text { days }\end{array}$ & - \\
\hline $\begin{array}{l}\text { Bassetti et al. } \\
(2014)[16]\end{array}$ & $69 / \mathrm{male}^{\mathrm{a}}$ & $\begin{array}{l}\text { Treatment for } \\
\text { peri-implantitis }\end{array}$ & $\begin{array}{l}\text { Air-powder abrasive } \\
\text { (Air-Flow Master }^{\circledast}, \\
\text { glycine powder) }\end{array}$ & $\begin{array}{l}\text { Subcutaneous, } \\
\text { pneumomediastinum }\end{array}$ & $\begin{array}{l}\text { Amoxicillin/clavulinic acid } \\
2.2 \mathrm{~g}(\mathrm{IV}) ; \text { resolved within } \\
7 \text { days }\end{array}$ & - \\
\hline \multirow[t]{3}{*}{$\begin{array}{l}\text { Alonso et al. } \\
(2017)[15]\end{array}$} & 73/male & $\begin{array}{l}\text { Peri-implant } \\
\text { cleaning }\end{array}$ & $\begin{array}{l}\text { Air-powder polishing } \\
\text { (sodium bicarbonate } \\
\text { powder) }\end{array}$ & Subcutaneous & $\begin{array}{l}\text { Methylprednisolone, } 40 \text { mg } \\
\text { (intramuscular) + azithromycin, } \\
500 \text { mg/day for } 3 \text { days; } \\
\text { resolved } 4 \text { days }\end{array}$ & - \\
\hline & 43/male & Teeth cleaning & $\begin{array}{l}\text { Air-powder polishing } \\
\text { (sodium bicarbonate } \\
\text { powder) }\end{array}$ & $\begin{array}{l}\text { Subcutaneous, } \\
\text { pneumomediastinum }\end{array}$ & $\begin{array}{l}12 \text { h of observation, no } \\
\text { antibiotics; resolved } 3 \text { to } \\
4 \text { days }\end{array}$ & - \\
\hline & 62/female & Teeth cleaning & $\begin{array}{l}\text { Air powder polishing } \\
\text { (sodium bicarbonate } \\
\text { powder) }\end{array}$ & Subcutaneous & $\begin{array}{l}\text { lbuprofen, } 600 \text { mg/ } 8 \text { h for } \\
5 \text { days and azithromycin } \\
500 \text { mg/day for } 3 \text { days; } \\
\text { resolved within } 5 \text { days }\end{array}$ & - \\
\hline Current report & $51 /$ female ${ }^{a}$ & $\begin{array}{l}\text { Cleaning for } \\
\text { peri-implantitis }\end{array}$ & Air powder abrasive & $\begin{array}{l}\text { Subcutaneous, } \\
\text { retropharynx, } \\
\text { pneumomediastinum }\end{array}$ & $\begin{array}{l}\text { Cephalosphorin + tazobactam } \\
\text { (IV); resolved within } 10 \text { days }\end{array}$ & - \\
\hline
\end{tabular}

Cavi-Jet and Prophy-Jet are registered trademarks of Dentsply Sirona, USA; Air-Flow Master is a registered trademark of EMS Dental, Nyons, France $C x$ complications, IV intravenous

${ }^{a}$ Cases of peri-implantitis treatment-related emphysema 


\section{Abbreviation}

$\mathrm{CT}$ : Computed tomography

\section{Authors' contributions}

STL and MGS drafted the manuscript. TGK and STL participated in the patient treatment. STL and TGK critically revised the manuscript. All authors read and approved the final manuscript.

\section{Ethics approval and consent to participate}

Not applicable.

\section{Consent for publication}

Written informed consent was obtained from the patient for the publication of this report and any accompanying images.

\section{Competing interests}

The authors declare that they have no competing interests.

\section{Publisher's Note}

Springer Nature remains neutral with regard to jurisdictional claims in published maps and institutional affiliations.

Received: 10 April 2018 Accepted: 20 April 2018

Published online: 05 June 2018

\section{References}

1. Uehara M, Okumura T, Asahina I (2007) Subcutaneous cervical emphysema induced by a dental air syringe: a case report. Int Dent J 57:286-288

2. Mitsunaga S, Iwai T, Aoki N, Yamashita Y, Omura S, Matsui Y, Maegawa J, Hirota M, Mitsudo K, Tohnai I (2013) Cervicofacial subcutaneous and mediastinal emphysema caused by air cooling spray of dental laser. Oral Surg Oral Med Oral Pathol Oral Radiol 115:e13-e16

3. Patel N, Lazow SK, Berger J (2010) Cervicofacial subcutaneous emphysema: case report and review of literature. J Oral Maxillofac Surg 68:1976-1982

4. Tastepe CS, van Waas R, Liu Y, Wismeijer D (2012) Air powder abrasive treatment as an implant surface cleaning method: a literature review. Int J Oral Maxillofac Implants 27:1461-1473

5. Schwarz F, Becker K, Bastendorf KD, Cardaropoli D, Chatfield C, Dunn I, Fletcher P, Einwag J, Louropoulou A, Mombelli A, Ower P, Pavlovic P, Sahrmann P, Salvi GE, Schmage P, Takeuchi Y, Van Der Weijden F, Renvert S (2016) Recommendations on the clinical application of air polishing for the management of peri-implant mucositis and peri-implantitis. Quintessence Int 47:293-296

6. Wakoh M, Saitou C, Kitagawa H, Suga K, Ushioda T, Kuroyanagi K (2000) Computed tomography of emphysema following tooth extraction. Dentomaxillofac Radiol 29:201-208

7. Goodnight JW, Sercarz JA, Wang MB (1994) Cervical and mediastinal emphysema secondary to third molar extraction. Head Neck 16:287-290

8. McKenzie WS, Rosenberg M (2009) latrogenic subcutaneous emphysema of dental and surgical origin: a literature review. J Oral Maxillofac Surg 67: $1265-1268$

9. Ely EW, Stump TE, Hudspeth AS, Haponik EF (1993) Thoracic complications of dental surgical procedures: hazards of the dental drill. Am J Med 95:456-465

10. Mather AJ, Stoykewych AA, Curran JB (2006) Cervicofacial and mediastinal emphysema complicating a dental procedure. J Can Dent Assoc 72:565-568

11. Heyman SN, Babayof I (1995) Emphysematous complications in dentistry, 1960-1993: an illustrative case and review of the literature. Quintessence Int 26:535-543

12. Arai I, Aoki T, Yamazaki H, Ota Y, Kaneko A (2009) Pneumomediastinum and subcutaneous emphysema after dental extraction detected incidentally by regular medical checkup: a case report. Oral Surg Oral Med Oral Pathol Oral Radiol Endod 107:e33-e38

13. Bergendal T, Forsgren L, Kvint S, Lowstedt E (1990) The effect of an airbrasive instrument on soft and hard tissues around osseointegrated implants. A case report. Swed Dent J 14:219-223

14. Liebenberg WH, Crawford BJ (1997) Subcutaneous, orbital, and mediastinal emphysema secondary to the use of an air-abrasive device. Quintessence Int 28:31-38

15. Alonso V, Garcia-Caballero L, Couto I, Diniz M, Diz P, Limeres J (2017) Subcutaneous emphysema related to air-powder tooth polishing: a report of three cases. Aust Dent J 62:510-515
16. Bassetti M, Bassetti R, Sculean A, Salvi GE (2014) Subcutaneous emphysema following non-surgical peri-implantitis therapy using an air abrasive device: a case report. Swiss Dent J 124:807-817

17. Finlayson RS, Stevens FD (1988) Subcutaneous facial emphysema secondary to use of the Cavi-Jet. J Periodontol 59:315-317

18. Kung JC, Chuang FH, Hsu KJ, Shih YL, Chen CM, Huang IY (2009) Extensive subcutaneous emphysema after extraction of a mandibular third molar: a case report. Kaohsiung J Med Sci 25:562-566

19. Strassen U, Bas M, Knopf A (2011) Visit at the dentist with consequences. HNO 59:1125-1128

\section{Submit your manuscript to a SpringerOpen ${ }^{\circ}$ journal and benefit from:}

- Convenient online submission

Rigorous peer review

- Open access: articles freely available online

- High visibility within the field

Retaining the copyright to your article

Submit your next manuscript at $\gg$ springeropen.com 